\title{
Antibody-mediated Rejection in Heart Transplantation
}

\author{
Abdallah G. Kfoury • Deborah Budge • \\ Jose Nativi-Nicolau • Rami A. Alharethi • \\ M. Elizabeth. H. Hammond • Dylan V. Miller
}

Published online: 13 September 2014

(C) Springer International Publishing AG 2014

\begin{abstract}
Heart transplantation is an excellent long-term treatment that confers functionality and longevity in select patients with end-stage heart failure. Yet, allograft rejection continues to pose a significant threat, especially in high-risk recipients and soon after transplantation. Of the two prevailing pathologic types of acute rejection in cardiac allografts, antibody-mediated rejection (AMR) had been variably defined and poorly understood for the past three decades when compared to cellular rejection. As a result, progress in understanding its pathologic and clinical behavior and the ability to find effective therapies had been hindered. Recent years have seen a renewed interest in cardiac AMR with efforts from pathologists, immunologists, and clinicians leading to a standardized diagnostic nomenclature.
\end{abstract}

\footnotetext{
A. G. Kfoury $(\bowtie) \cdot$ D. Budge $\cdot$ R. A. Alharethi $\cdot$

M. E. H. Hammond • D. V. Miller

UTAH Cardiac Transplant Program, Intermountain Heart Institute,

5121 S. Cottonwood Street, LL1, Salt Lake City, UT 84107, USA

e-mail: akfoury@imail.org

D. Budge

e-mail: Deborah.Budge@imail.org

R. A. Alharethi

e-mail: Rami.Alharethi@imail.org

M. E. H. Hammond

e-mail: liz.hammond@hotmail.com

D. V. Miller

e-mail: Dylan.miller@imail.org

A. G. Kfoury · J. Nativi-Nicolau • M. E. H. Hammond - D. V. Miller University of Utah School of Medicine, 30 N 1900 E, 4A100, Salt Lake City, UT 84132, USA

J. Nativi-Nicolau

e-mail: jose.nativi@hsc.utah.edu
}

Keywords Antibody-mediated Rejection · Humoral Rejection · Vascular Rejection · Heart Transplantation

\section{Introduction}

The initial indirect report of a possible humoral recipient response, detrimental to the cardiac allograft and manifesting as arteriolar vasculitis, surfaced in the late 1980's from Johns Hopkins [1]. Soon after in 1989, Hammond et al., in Utah followed with the first comprehensive description of the pathological features and clinical outcomes of vascular or humoral rejection in heart transplantation [2•]. The next two decades saw a lot of uncertainty and skepticism as to whether cardiac antibody-mediated rejection (AMR) even existed and, if so, how to best define it. Under the auspices of the International Society of Heart and Lung Transplantation (ISHLT), multidisciplinary consensus meetings including pathologists and clinicians recently succeeded in the standardization and refinement of diagnostic criteria for AMR in heart transplantation. Despite this important milestone, therapies for cardiac AMR and their outcome are still limited to individual transplant centers' experience, and there is a need of rigorous prospective testing on a larger scale.

\section{Associated Risk Factors}

In adult heart transplants, AMR is more frequent in young [2•, $3]$ and female recipients [3-7]. In pediatric heart transplants congenital heart disease is a frequent predictor of AMR $[8,9]$.

The formation of antibodies against Human Leukocyte Antigen (HLA) in sensitized patients is a main predisposing 
factor for AMR $[2 \bullet, 4,6]$. However, pathological AMR can also occur in the absence of preformed antibodies [9], and the presence or absence of donor-specific antibodies (DSA) does not confirm or exclude the diagnosis of AMR. Therefore, in the 2011 ISHLT consensus report, DSA detection supports the diagnosis of AMR, but it is not essential for diagnosis [10•]. Conditions associated with sensitization include previous transfusions, pregnancies, transplantations, and mechanical circulatory support [3,11-13]. Prior transplantation stimulates the production of de-novo anti-HLA [14-16], and the development of non-HLA antibodies directed against cardiac myosin and vimentin, which have also been associated with the development of AMR [17]. The growing practice of bridging heart transplant recipients with left ventricular assist devices (LVAD) is known to promote the development of alloantibodies, probably from interaction between the LVAD surface and the immune system. Additionally, the transfusion of platelet products during LVAD support is associated with the development of HLA class I IgG antibodies [12, 18-21]. The type of circulatory support is related to the degree of sensitization as the first-generation LVADs with pulsatile flow and biomaterial surfaces produced more allosensitization compared to second generation LVADs with continuous-flow mechanisms [19, 22].

Several observational studies have linked the presence of a positive crossmatch between donor cells and recipient serum with subsequent development of AMR $[2 \bullet, 6,7,23$, 16, 24]. More specific and sensitive antibody-detection assays and the use of virtual crossmatching before transplantation have decreased the frequency of positive donorrecipient crossmatches.

Prolonged allograft ischemic time is a known factor for decreased survival after heart transplantation. The ischemia/ reperfusion injury is a complex inflammatory response [25] that triggers the host immune system in a potentially similar way observed during AMR [26]. Despite a potential mechanistic role, prolonged ischemia has not to date been associated with higher frequencies of AMR [7, 27].

Preoperative seropositive status for cytomegalovirus (CMV), and the grafting of organs from seropositive donors or a postoperative CMV infection, are associated with an increased risk of AMR, chronic rejection, and allograft vasculopathy $[28,29]$.

\section{Immunology/Pathways of Cardiac AMR}

The pathogenesis of AMR involves the activation of the innate and the adaptive immune systems, mostly targeting the endothelium of the cardiac microvasculature. New data also suggest a preponderant role of ischemia/reperfusion injury of the cardiac allograft.
The Innate Immune System

The innate immune system is the evolutionary first line of defense against invaders/injury. It is nonspecific and involves several mobile and stationary cells (dendritic cells) that inspect the extracellular space and cytoplasm for the presence of pathogen-associated molecular patterns (PAMPs) as well as damage-associated molecular patterns (DAMPs) [30]. The system involves pattern recognition receptors (PRRs) on these cells that respond to specific pathogens or injury associated molecular profiles [26, 31-34]. The recognition of antigens triggers an inflammatory response, which includes cytokine signaling, complement activation, and leucocyte chemotaxis. Similar to the recipient, the donor immune system can also be activated by pathogens, toxins, and reactive oxygen species (ROS) released during brain death conditions [30].

\section{The Adaptive Immune System}

By contrast, adaptive immunity is highly specific and is triggered by the recognition of specific antigens [35-38]. T and B lymphocytes recognize foreign antigen and proliferate, with subsequent B-lymphocyte activation to memory cells and antibody-producing plasma cells. Fully activated B lymphocytes possess surface markers CD 19, part of the antigen receptor, and CD 20, which is a marker of complement activation [39-41]. Plasma cells produce large quantities of an antigen-specific antibody, are incapable of antigen recognition, and do not possess the usual B-cell markers, CD19 and CD20 [42-44].

The endothelium is the main site of action during AMR. Antibodies bind to MHC antigens on the vascular endothelium and may or may not fix complement, which can accelerate the level of injury of the endothelium. C4d and C3d are split products that bind covalently to endothelium and can be used as reliable markers for complement activation [38]. Importantly, the antibodies also can bind to other immune effector cells with receptors for the $\mathrm{Fc}$ portion of the immunoglobulin molecule, including macrophages, NK cells, B lymphocytes, neutrophils, and platelets, which further accelerate allograft injury $[31,34,36,45,46]$. Overall, the adaptive immune system generates specific effector mechanisms including antibody production, complement activation, coagulation, and CD8 mediated cytotoxicity in the endothelium.

Ischemia/Reperfusion Injury of the Allograft

Ischemia-reperfusion-injury (IRI) is a complex inflammatory response that involves both the innate and adaptive immune systems. It has been described during organ transplantation, trauma, autoimmune diseases, and revascularization [25]. Post-ischemic-reperfusion damage is postulated to occur from the combined release of ROS from donor-derived vascular 
cells and from recipient-derived neutrophils entering the graft during reperfusion. The release of ROS is the main mechanism of cell injury and death. The production of DAMPs is then identified by PRRs triggering inflammatory responses of the innate and adaptive systems with the potential of subsequent AMR $[25,30]$.

\section{Pathology of Cardiac AMR}

\section{ISHLT Working Formulation for Cardiac AMR}

Recognition of cardiac AMR has evolved over the past three decades from controversial single- center reports $[2 \cdot, 47]$ to consensus guideline defined criteria. In 2010, an international multidisciplinary effort was initiated by the ISHLT with the aim of standardizing terminology, definitions, and practices to help facilitate multicenter clinical trials [48]. In a departure from the previous 2005 ISHLT working formulation (WF), the pathologic diagnosis of AMR was separated from the clinical and serologic aspects [49]. The new grades of pathologic AMR were given a "p" prefix to indicate that only pathologic criteria are considered [50••]. The $2013 \mathrm{WF}$ AMR grades were also broadened from a binary present/absent (AMR0/AMR1) to a graduated scale as shown in Table 1 .

\section{Surveillance Strategies and Biopsy Handling}

The morphologic, immunopathologic, serologic, and clinical features of AMR may fluctuate over time and do not always coincide [51]. The histopathologic features should be assessed in every biopsy. If not done on every biopsy, then at a minimum immunopathology should be done when there is clinical graft dysfunction or when histologic or serologic features suggest AMR. During the first year after the post-transplant, routine immunopathology should be included, if biopsies are done, for biopsies at two and four weeks after transplant and again at three, six, and 12 months [50••].

Both frozen section immunofluorescence (IF) and paraffin section immunoperoxidase (IP) are acceptable immunopathology techniques. For frozen IF, a separate unfixed biopsy piece is required. Sections of the frozen tissue should be examined by routine histology along with the fluorescence stained slides. For IF, the recommended stains include $\mathrm{C} 4 \mathrm{~d}$ and C3d. For IP, C4d and CD68 are recommended. Other optional stains are also outlined in the 2013 WF document [50••]. Proper assay optimization, validation, and controls are critical.

\section{Histopathologic Features}

The first suggestion of AMR by histopathology may be a "busy" hypercellular appearance of the interstitium at low magnification. On closer inspection the conspicuous cells are largely confined to distended lumens of capillaries and venules and consist of enlarged "swollen" endothelial cells with rounded rather than flattened nuclei along with macrophages and other mononuclear inflammatory cells (Fig. 1). The chromatin patterns of activated endothelial cells and macrophages are similar and not readily distinguishable in many cases, so the $2013 \mathrm{WF}$ terms these "intravascular activated mononuclear cells". If CD68 staining is not routinely done, cases with even focally prominent intravascular mononuclear cells should prompt staining for CD68 [50••]. Other less common features of AMR by light microscopy include edema and hemorrhage in the interstitium. Extravascular inflammation is more prominent in severe AMR, along with edema, hemorrhage, endothelial cell pyknosis/karyorrhexis, and extensive myocyte damage [52].

Immunopathologic Features

The hallmark immunopathologic features of AMR include detecting complement cascade activation by staining for complement split products (e.g., C3d and C4d), and confirming the presence of intravascular macrophages using monocyte lineage antigen (CD68) staining [50••] (Fig. 2). Complement staining and CD68 positive macrophage accumulation are usually concomitant, but one may precede the other in some cases [53].

Interpretation of immunopathology findings can be challenging. The 2013 ISHLT WF outlines an approach incorporating tissue specificity, intensity, and distribution of staining. Regarding tissue specific staining, only myocardial capillary staining is considered significant. In terms of intensity and distribution, specific scoring schemes are outlined. Intensity is scored subjectively as 0 (negative), 1 (weak), and 2 (strong), and distribution is reported as 0 (negative; $<10 \%$ of vessels in the total surface area), 1 (focal; $10-50 \%$ ), and 2 (multifocal/ diffuse; $>50 \%$ ). Complement staining is considered positive if the intensity is $>0$ and the distribution is 2 regardless of technique. For CD68, intensity is not a consideration, but positive is defined as any score $>0[50 \bullet \cdot$.

\section{Biopsy Mimics of AMR}

The histologic features of AMR are not entirely specific [49] and complement activation in the graft can occur through mechanisms other than rejection [54]. Biopsy grading may be challenging during the first two weeks after transplant because endothelial injury associated with harvesting ischemia/reperfusion overlaps significantly with AMR, and may have some complement activation. The use of the murine anti-CD3 antibody OKT3 can also incite a reaction mimicking AMR [55]. Macrophages are components of other processes besides ACR, and the 2013 ISHLT WF stipulates 
Table 1 The 2013 ISHLT Working Formulation for Pathologic Diagnosis of Cardiac AMR

\begin{tabular}{lll}
\hline Grade & Definition & Criteria \\
\hline pAMR 0 & Negative for pathologic AMR & Histologic and immunopathologic findings are both absent \\
pAMR 1 $(\mathrm{H}+)$ & Histopathologic AMR alone & Histologic findings are present and immunopathologic findings are absent \\
pAMR 1 $(\mathrm{I}+)$ & Immunopathologic AMR alone & Histologic findings are absent and immunopathologic findings are present \\
pAMR 2 & Pathologic AMR & Histologic and immunopathologic findings are both present \\
pAMR 3 & Severe pathologic AMR & $\begin{array}{l}\text { Interstitial hemorrhage, capillary fragmentation, mixed inflammatory } \\
\text { infiltrates, endothelial cell pyknosis, and/or karyorrhexis, and marked } \\
\end{array}$ \\
& & edema with immunopathologic findings are present. \\
\hline
\end{tabular}

ISHLT, International Society for Heart and Lung Transplantation; AMR, antibody-mediated rejection

that CD68 (and C4d) should be assessed on intact myocardium away from areas of cellular rejection, Quilty lesions, biopsy site scars, and areas of ischemic-related damage or necrosis $[50 \bullet \cdot$.

Controversies in the Pathology of AMR

While as a concept AMR has gained near universal acceptance in the cardiac transplant field, there are still substantial gaps in understanding the pathogenic mechanisms and especially the prognostic weight of individual (or combined) pathologic AMR features. For example, there is some evidence that detection of both $\mathrm{C} 3 \mathrm{~d}$ and $\mathrm{C} 4 \mathrm{~d}$ deposition (as opposed to $\mathrm{C} 4 \mathrm{~d}$ alone) in biopsies is more ominous; presumably because $\mathrm{C} 3$ cleavage signals the failure of complement regulators to halt progression down the complement cascade [56]. The relative significance of pAMR1 versus pAMR2 rejection patterns also needs further study [57]. The combined presence of both cellular rejection and AMR is increasingly recognized and deserves attention in terms of possible cross-
Fig. 1 Histopathology of Cardiac AMR a) Low-power

photomicrograph of a transplant endomyocardial biopsy showing a "busy appearance" in the interstitium, typical of AMR (H\&E stain, 20×; courtesy Desley Niel, MD). b \& c) Higher power photomicrographs showing cross-sections of capillaries and venules with prominent swollen endothelium and activated intravascular mononuclear cells (H\&E stain, $400 \times$ ). d) High-power photomicrograph of a biopsy showing severe AMR with interstitial edema and extensive capillary injury and karyorrhexis (H\&E stain, 200×)
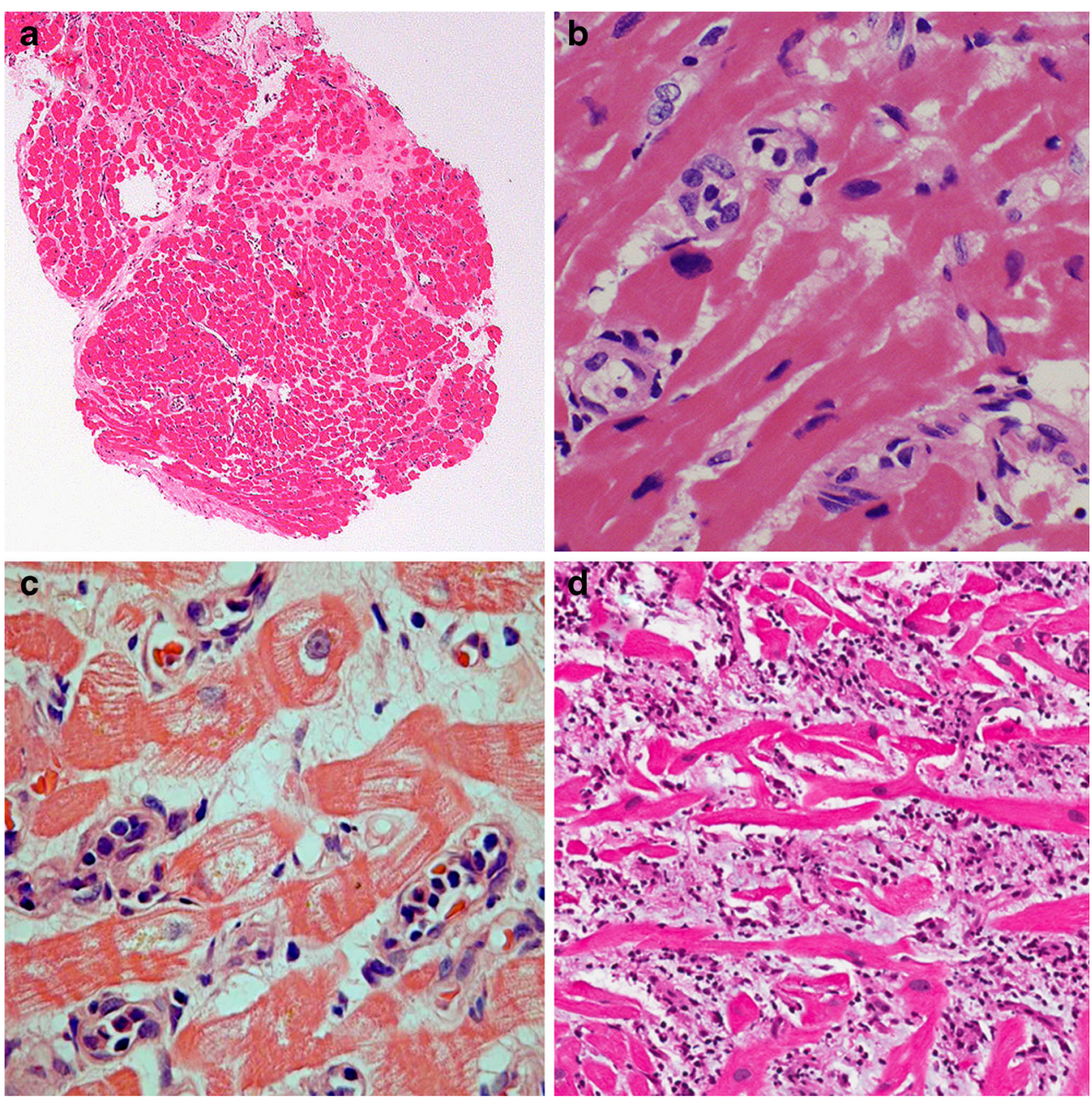
Fig. 2 Immunopathology of Cardiac AMR a) Fluorescence photomicrograph of a transplant endomyocardial biopsy frozen section stained by C4d immunofluorescence showing diffuse strong capillary "donut" staining (IF stain, 100x). b) Fluorescence photomicrograph showing a positive $\mathrm{C} 3 \mathrm{~d}$ immunofluorescence pattern (IF stain, 200×). c) High-power photomicrograph of a biopsy paraffin section stained by $\mathrm{C} 4 \mathrm{~d}$ immunoperoxidase showing diffuse strong capillary "donut" staining (IP stain, $400 \times$ ). Photomicrograph of a CD68 stained paraffin section showing aggregation of intravascular CD68 positive macrophages (IP stain, 400×)
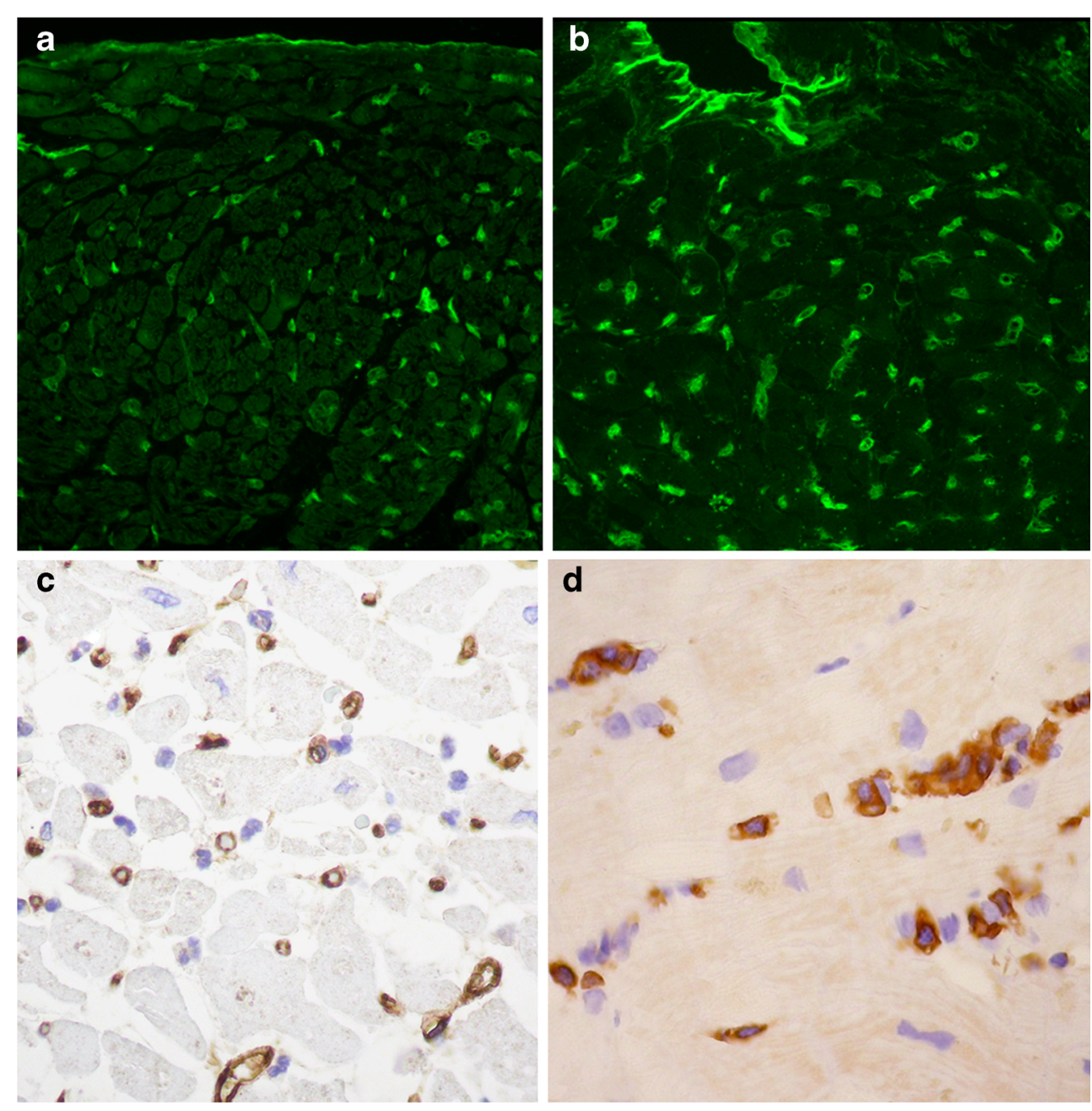

d

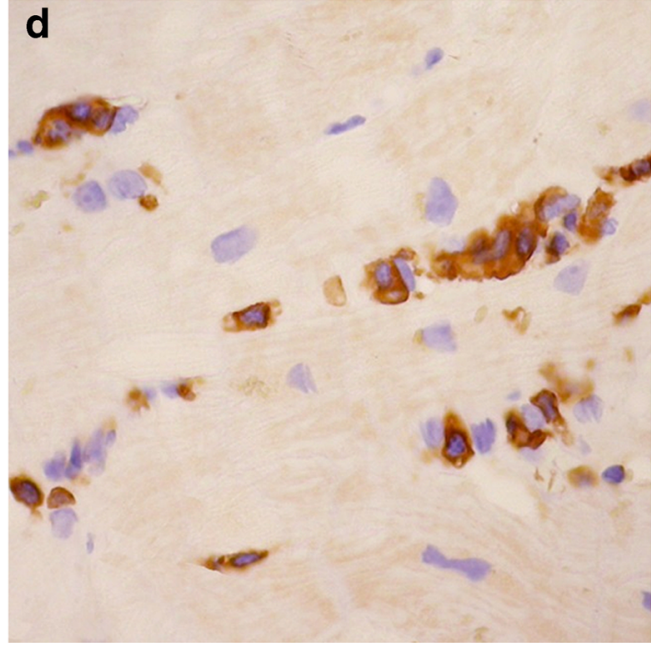

reacting immune mechanisms as well as the most appropriate therapeutic strategies for "mixed" rejection.

\section{Clinical Features}

It is likely that cardiac AMR is underreported since screening in asymptomatic patients is not routinely done. While its true incidence remains unknown, the prevalence of lone AMR is around $10 \%$ to $15 \%$, and is conceivably higher when diagnosed concomitantly with cellular rejection (mixed rejection) [58-61].

A number of clinical features are characteristic of AMR. It tends to occur early especially in sensitized patients and the risk of recurrence is high particularly in recipients who have three or more separate AMR episodes in the first three months after transplant. Most AMR occurrences are mild but symptomatic patients are more likely to present with hemodynamic compromise and cardiac dysfunction when compared to cellular rejection. The course of cardiac AMR depends on its severity and the time of diagnosis. More severe cases and those happening early after transplant are less likely to recover and/or resolve, and the associated outcomes are worse. Cardiac AMR, whether clinically silent or symptomatic, has uniformly been associated with cardiac allograft vasculopathy, chronic graft dysfunction, and higher mortality. In some cases sudden cardiac death is still seen despite successful therapy of the acute AMR with pathological and clinical resolution; in these cases we have usually found an aggressive and diffuse form of cardiac allograft vasculopathy at autopsy $[2 \cdot, 4,5,7,15,24,60,62-72]$.

\section{Management of Cardiac AMR}

After a diagnosis of AMR is made by pathological findings, the decision of whether to treat requires consideration of the patient's clinical presentation, allograft function, biopsy grade, and the presence of donor-specific antibodies. General recommendations for the treatment of AMR were published by the ISHLT in 2010 [73]. Overall, the treatment of AMR is 
complex as there are multiple therapeutic targets in the alloantibody response, including T-cell and B-cell activity, antibody removal and production, and antibody effect.

\section{ISHLT Guidelines*[73]}

\section{Class IIa}

1. The following treatments can be used to disrupt the immune-mediated injury of the heart allograft in AMR: (1) high-dose intravenous (IV) corticosteroids; and (2) cytolytic immunosuppressive therapy.

2. The following treatments may be used to remove circulating anti-HLA antibodies or decrease their reactivity: (1) plasmapheresis; (2) immune apheresis (immunoadsorption); and (3) IVIg.

3. The following treatments are used to maintain adequate cardiac output and systemic blood pressure: (1) IV inotropes and vasopressors; and (2) mechanical circulatory support.

4. When AMR is suspected, EMB examination should be expanded to include immunohistochemistry stains for complement split products and possible antibodies.

5. Recipient serum should be screened for presence, quantity, and specificity of anti-donor (HLA) antibodies.

6. Follow-up EMB should be performed one to four weeks after initiation of therapy and should include immunohistochemistry examination.

7. Adjustment of maintenance immunosuppressive therapy may be considered. This can include increase in the dose of current immunosuppressive agent(s), addition of new agent(s) or conversion to different agent(s).

\section{Class IIb}

1. Systemic anticoagulation may decrease intravascular thrombosis in the heart allograft.

2. Emergent retransplantation may be considered if the above measures do not restore acceptable heart allograft function, but outcomes in this situation are unfavorable.

*All recommendations are Level of Evidence C.

\section{Antibody removal and inhibition}

Immunoadsorption (IA), plasmapheresis (PP), and therapeutic plasma exchange (TPE) effectively and quickly remove circulating antibodies and have been used for desensitization and treatment of AMR [43, 68, 74 76]. No randomized trials of these therapies have been done in cardiac transplantation, and the small number that have been performed with kidney transplant recipients have had mixed results [77-81]. When used, additional therapies targeting antibody activity or production are often given concurrently to minimize the rapid rebound in antibody titers that can occur following treatment. The activity of circulating antibodies can also be targeted, most commonly with intravenous immunoglobulin (IVIg). Potential mechanisms by which IVIg may be effective in the treatment of AMR include the expansion of regulatory T cells, upregulation of the inhibitory FcyRIIB receptor on B cells, and the suppression of complement activation [82-84]. There is very little data from clinical trials examining the use of IVIg in transplants; however, it is commonly used for treatment of AMR, often in combination with PP and/or agents that target antibody production [85-87]. Finally, eculizumab is an antibody directed against the complement component $\mathrm{C} 5$ that effectively blocks the antibody-triggered complement cascade. Case reports describe successful use in the treatment of AMR in renal and lung transplant recipients; however, additional data is needed prior to routine use in cardiac transplantation [88-94].

\section{Antibody production}

Therapies to decrease the production of antibodies target $\mathrm{B}$ cells and plasma cells. The anti-CD20 antibody rituximab, which acts through the elimination of peripheral B cells, has been increasingly used. The efficacy of rituximab for the treatment of AMR has been difficult to assess as it is always part of a multitherapy strategy. Its therapeutic effect may have limits as CD20 is not present on pro-B cells or mature plasma cells; therefore, rituximab does not prevent the regeneration of B cells and may not directly decrease immunoglobulin levels. Data of its efficacy in the treatment of AMR in cardiac transplant recipients consists of case reports and retrospective observational studies [64, 95-101]. Results are mixed, with the most recently published series showing a survival benefit in those treated with rituximab [101].

B-cell depletion is also achieved with the administration of antibodies, which bind other antigens expressed on the surface of B cells and include the anti-CD52 antibody alemtuzumab as well as antithymocyte globulin [102-106]. Potential future agents target other B-cell inhibitory and costimulatory receptors [107-118]. With all of these agents, an awareness of the potential unwanted effects of B-cell depletion is needed [119]. For example, regulatory $\mathrm{B}$ cells may play an important role in promoting tolerance. Further research is needed to identify 
optimal treatment regimens that balance the effects of Bcell depletion with rejection and graft survival.

Plasma cells are an additional, and perhaps preferred, target to reduce antibody production. Case reports describe the use of bortezomib, a proteasome inhibitor that preferentially targets alloantibody-producing plasma cells, in the successful treatment of AMR in cardiac transplant recipients [120-124]. As with other agents, toxicities have been reported, and randomized controlled trials are needed prior to widespread adoption.

\section{T-cell inhibition}

B-cell activity is tightly regulated by T-cells; therefore, therapy targeting T-cell activity is an important aspect of treatment for AMR. Antithymocyte globulin (ATG) has multiple T-cell targets, and may also be effective in the treatment of AMR beyond its inhibition of T-cells as it contains antibodies to Bcell and plasma cell antigens[125, 126]. It is generally used in moderate to severe cases of AMR associated with graft dysfunction and/or hemodynamic compromise. Unlike with ATG, there is no conclusive evidence for activity on T-cellindependent B-cell antibody production with the calcineurin inhibitors. The mTOR inhibitors such as rapamycin, however, may inhibit B-cell antibody production and proliferation via T-cell-independent mechanisms [127, 128]. Therefore, changing from MMF to rapamycin or the addition of rapamycin is a reasonable strategy in a patient with AMR.

Glucocorticoids bind to glucocorticoid receptors on T cells, antigen presenting cells, and immunosuppressive effects are many and varied. For AMR associated with hemodynamic abnormalities, high-dose corticosteroids (methylprednisolone $1000 \mathrm{mg}$ IV daily for three consecutive days) should be used. In less severe cases, an oral bolus dose may be used.

In our experience, fatal acute AMR seems to be a prothrombotic state with microvascular thrombi often seen on necropsy, yet whether systemic anticoagulation helps in outcome remains unsettled.

\section{Conclusion}

Cardiac AMR now has ISHLT-sanctioned defining pathologic criteria. Consensus publications also recommend periodic monitoring of DSA especially early after transplantation and in high-risk recipients. Successes with therapies for cardiac AMR are moderate at best and limited to case reports and small series. The field is in much need of prospective randomized trials to standardize an optimal management approach to this vexing clinical problem in heart transplantation. Emerging animal models of AMR will further our understanding of its pathophysiology and possibly help in devising new treatment strategies.

\section{Compliance with Ethics Guidelines}

Conflict of Interest AG Kfoury, D Budge, J Nativi-Nicolau, RA Alharethi, MEH Hammond, and DV Miller all declare no conflicts of interest.

Human and Animal Rights and Informed Consent All studies by the authors involving animal and/or human subjects were performed after approval by the appropriate institutional review boards. When required, written informed consent was obtained from all participants.

\section{References}

Papers of particular interest, published recently, have been highlighted as:

- Of importance

•. Of major importance

1. Herskowitz A, Soule LM, Ueda K, Tamura F, Baumgartner WA, Borkon AM, et al. Arteriolar vasculitis on endomyocardial biopsy: a histologic predictor of poor outcome in cyclosporine-treated heart transplant recipients. J Heart Trans. 1987;6(3):127-36.

2. Hammond EH, Yowell RL, Nunoda S, Menlove RL, Renlund DG, Bristow MR, et al. Vascular (humoral) rejection in heart transplantation: pathologic observations and clinical implications. J Heart Trans. 1989;8(6):430-43. This is the first comprehensive report of AMR in heart transplantation.

3. Nwakanma LU, Williams JA, Weiss ES, Russell SD, Baumgartner WA, Conte JV. Influence of pretransplant panel-reactive antibody on outcomes in 8,160 heart transplant recipients in recent era. Ann Thorac Surg. 2007;84(5):1556-62. doi:10.1016/j.athoracsur. 2007.05.095. discussion 62-3.

4. Hammond EH, Yowell RL, Price GD, Menlove RL, Olsen SL, O'Connell JB, et al. Vascular rejection and its relationship to allograft coronary artery disease. J Heart Lung Trans Off Publ Int Soc Heart Trans. 1992;11(3 Pt 2):S111-9.

5. Lones MA, Czer LS, Trento A, Harasty D, Miller JM, Fishbein MC. Clinical-pathologic features of humoral rejection in cardiac allografts: a study in 81 consecutive patients. J Heart Lung Trans Off Publ Int Soc Heart Trans. 1995;14(1 Pt 1):151-62.

6. McCarthy JF, Cook DJ, Smedira NG, O'Malley KJ, Massad MG, Sano Y, et al. Vascular rejection in cardiac transplantation. Transplant Proc. 1999;31(1-2):160.

7. Michaels PJ, Espejo ML, Kobashigawa J, Alejos JC, Burch C, Takemoto S, et al. Humoral rejection in cardiac transplantation: risk factors, hemodynamic consequences and relationship to transplant coronary artery disease. J Heart Lung Trans Off Publ Int Soc Heart Trans. 2003;22(1):58-69.

8. Casarez TW, Perens G, Williams RJ, Kutay E, Fishbein MC, Reed $\mathrm{EF}$, et al. Humoral rejection in pediatric orthotopic heart transplantation. J Heart Lung Trans Off Publ Int Soc Heart Trans. 2007;26(2):114-9. doi:10.1016/j.healun.2006.11.011.

9. Everitt MD, Hammond ME, Snow GL, Stehlik J, Revelo MP, Miller DV, et al. Biopsy-diagnosed antibody-mediated rejection 
based on the proposed International Society for Heart and Lung Transplantation working formulation is associated with adverse cardiovascular outcomes after pediatric heart transplant. J Heart Lung Trans Off Publ Int Soc Heart Trans. 2012;31(7):686-93. doi: 10.1016/j.healun.2012.03.009.

10. Kobashigawa J, Crespo-Leiro MG, Ensminger SM, Reichenspurner H, Angelini A, Berry G, et al. Report from a consensus conference on antibody-mediated rejection in heart transplantation. J Heart Lung Trans Off Publ Int Soc Heart Trans. 2011;30(3):252-69. doi:10.1016/j.healun.2010.11.003. An important report of the first large consensus meeting on cardiac AMR.

11. Ginwalla M, Pando MJ, Khush KK. Pregnancy-related human leukocyte antigen sensitization leading to cardiac allograft vasculopathy and graft failure in a heart transplant recipient: a case report. Transplant Proc. 2013;45(2):800-2. doi:10.1016/j. transproceed.2012.10.038.

12. Moazami N, Itescu S, Williams MR, Argenziano M, Weinberg A, Oz MC. Platelet transfusions are associated with the development of anti-major histocompatibility complex class I antibodies in patients with left ventricular assist support. J Heart Lung Trans Off Publ Int Soc Heart Trans. 1998;17(9):876-80.

13. O'Boyle PJ, Smith JD, Danskine AJ, Lyster HS, Burke MM, Banner NR. De novo HLA sensitization and antibody mediated rejection following pregnancy in a heart transplant recipient. Am J Trans Off J Am Soc Trans Am Soc Transplant Surg. 2010;10(1): 180-3. doi:10.1111/j.1600-6143.2009.02875.x.

14. Jordan SC, Quartel AW, Czer LS, Admon D, Chen G, Fishbein $\mathrm{MC}$, et al. Posttransplant therapy using high-dose human immunoglobulin (intravenous gammaglobulin) to control acute humoral rejection in renal and cardiac allograft recipients and potential mechanism of action. Transplantation. 1998;66(6):800-5.

15. Cherry R, Nielsen H, Reed E, Reemtsma K, Suciu-Foca N, Marboe CC. Vascular (humoral) rejection in human cardiac allograft biopsies: relation to circulating anti-HLA antibodies. J Heart Lung Trans Off Publ Int Soc Heart Trans. 1992;11(1 Pt 1):24-9. discussion 30.

16. Greger B, Grossmann T, Gartner HV, Hopt UT, Lauchart W. Positive postoperative donor-specific crossmatch correlates with B-cell infiltration and poor graft prognosis. Transplant Proc. 1990;22(4):1900-2.

17. Nath DS, Ilias Basha H, Tiriveedhi V, Alur C, Phelan D, Ewald $\mathrm{GA}$, et al. Characterization of immune responses to cardiac selfantigens myosin and vimentin in human cardiac allograft recipients with antibody-mediated rejection and cardiac allograft vasculopathy. J Heart Lung Trans Off Publ Int Soc Heart Trans. 2010;29(11):1277-85. doi:10.1016/j.healun.2010.05.025.

18. John R, Lietz K, Schuster M, Naka Y, Rao V, Mancini DM, et al. Immunologic sensitization in recipients of left ventricular assist devices. J Thorac Cardiovasc Surg. 2003;125(3):578-91. doi:10. 1067/mtc.2003.30.

19. George I, Colley P, Russo MJ, Martens TP, Burke E, Oz MC, et al. Association of device surface and biomaterials with immunologic sensitization after mechanical support. J Thorac Cardiovasc Surg. 2008;135(6):1372-9. doi:10.1016/j.jtcvs.2007.11.049.

20. Joyce DL, Southard RE, Torre-Amione G, Noon GP, Land GA, Loebe M. Impact of left ventricular assist device (LVAD)-mediated humoral sensitization on post-transplant outcomes. J Heart Lung Trans Off Publ Int Soc Heart Trans. 2005;24(12):2054-9. doi:10.1016/j.healun.2005.06.028.

21. Bull DA, Reid BB, Selzman CH, Mesley R, Drakos S, Clayson S, et al. The impact of bridge-to-transplant ventricular assist device support on survival after cardiac transplantation. J Thorac Cardiovasc Surg. 2010;140(1):169-73. doi:10.1016/j.jtcvs.2010. 03.026.
22. Nativi JN, Drakos SG, Kucheryavaya AY, Edwards LB, Selzman $\mathrm{CH}$, Taylor DO, et al. Changing outcomes in patients bridged to heart transplantation with continuous- versus pulsatile-flow ventricular assist devices: an analysis of the registry of the International Society for Heart and Lung Transplantation. J Heart Lung Trans Off Publ Int Soc Heart Trans. 2011;30(8): 854-61. doi:10.1016/j.healun.2011.03.019.

23. Loy TS, Bulatao IS, Darkow GV, Demmy TL, Reddy HK, Curtis $\mathrm{J}$, et al. Immunostaining of cardiac biopsy specimens in the diagnosis of acute vascular (humoral) rejection: a control study. $\mathrm{J}$ Heart Lung Trans Off Publ Int Soc Heart Trans. 1993;12(5):73640.

24. Ensley RD, Hammond EH, Renlund DG, Yowell RL, Bristow MR, DeWitt CW, et al. Clinical manifestations of vascular rejection in cardiac transplantation. Transplant Proc. 1991;23(1 Pt 2): $1130-2$.

25. Ioannou A, Dalle Lucca J, Tsokos GC. Immunopathogenesis of ischemia/reperfusion-associated tissue damage. Clin Immunol. 2011;141(1):3-14. doi:10.1016/j.clim.2011.07.001.

26. Land WG. Emerging role of innate immunity in organ transplantation part II: potential of damage-associated molecular patterns to generate immunostimulatory dendritic cells. Transplant Rev. 2012;26(2):73-87. doi:10.1016/j.trre.2011.02.003.

27. Singhal AK, Drakos SG, Kfoury AG, Horne BD, Verma DR, Stehlik J. Prolonged allograft ischemic time is not associated with higher incidence of antibody-mediated rejection. J Heart Lung Trans Off Publ Int Soc Heart Trans. 2010;29(10):1198-200. doi: 10.1016/j.healun.2010.05.028.

28. Colvin-Adams M, Agnihotri A. Cardiac allograft vasculopathy: current knowledge and future direction. Clin Transpl. 2011;25(2): 175-84. doi:10.1111/j.1399-0012.2010.01307.x.

29. Watkins RR, Lemonovich TL, Razonable RR. Immune response to CMV in solid organ transplant recipients: current concepts and future directions. Expert Rev Clin Immunol. 2012;8(4):383-93. doi:10.1586/eci.12.25.

30. Land WG. Emerging role of innate immunity in organ transplantation: part I: evolution of innate immunity and oxidative allograft injury. Transplant Rev. 2012;26(2):60-72. doi:10.1016/j.trre. 2011.05.001.

31. Wyburn KR, Jose MD, Wu H, Atkins RC, Chadban SJ. The role of macrophages in allograft rejection. Transplantation. 2005;80(12):1641-7.

32. Andrade CF, Waddell TK, Keshavjee S, Liu M. Innate immunity and organ transplantation: the potential role of toll-like receptors. Am J Transplant Off J Am Soc Transplant Am Soc Transplant Surg. 2005;5(5):969-75. doi:10.1111/j.1600-6143.2005.00829.x.

33. Land WG. Innate immunity-mediated allograft rejection and strategies to prevent it. Transplant Proc. 2007;39(3):667-72. doi:10. 1016/j.transproceed.2007.01.052.

34. Nace G, Evankovich J, Eid R, Tsung A. Dendritic cells and damage-associated molecular patterns: endogenous danger signals linking innate and adaptive immunity. J Innate Immun. 2012;4(1): 6-15. doi:10.1159/000334245.

35. Lakkis FG, Sayegh MH. Memory T cells: a hurdle to immunologic tolerance. J Am Soc Nephrol JASN. 2003;14(9):2402-10.

36. Murata K, Baldwin 3rd WM. Mechanisms of complement activation, $\mathrm{C} 4 \mathrm{~d}$ deposition, and their contribution to the pathogenesis of antibody-mediated rejection. Transplant Rev. 2009;23(3):139-50. doi:10.1016/j.trre.2009.02.005.

37. Pietra BA. Transplantation immunology 2003: simplified approach. Pediatr Clin N Am. 2003;50(6):1233-59.

38. Wasowska BA. Mechanisms involved in antibody- and complement-mediated allograft rejection. Immunol Res. 2010;47(1-3):25-44. doi:10.1007/s12026-009-8136-3.

39. Coelho V, Saitovitch D, Kalil J, Silva HM. Rethinking the multiple roles of B cells in organ transplantation. Curr Opin Organ 
Transplant. 2013;18(1):13-21. doi:10.1097/MOT. 0b013e32835c8043.

40. Baldwin 3rd WM, Halushka MK, Valujskikh A, Fairchild RL. B cells in cardiac transplants: from clinical questions to experimental models. Semin Immunol. 2012;24(2):122-30. doi:10.1016/j. smim.2011.08.017.

41. Kwun J, Bulut P, Kim E, Dar W, Oh B, Ruhil R, et al. The role of B cells in solid organ transplantation. Semin Immunol. 2012;24(2): 96-108. doi:10.1016/j.smim.2011.08.022.

42. Barnett N, Dorling A, Mamode N. B cells in renal transplantation: pathological aspects and therapeutic interventions. Nephrol Dial Transplant Off Publ Eur Dial Transplant Assoc Eur Renal Association. 2011;26(3):767-74. doi:10.1093/ndt/gfq716.

43. Nair N, Ball T, Uber PA, Mehra MR. Current and future challenges in therapy for antibody-mediated rejection. J Heart Lung Transplant Off Publ Int Soc Heart Transplant. 2011;30(6):612-7. doi:10.1016/j.healun.2011.02.002.

44. Gareau A, Hirsch GM, Lee TD, Nashan B. Contribution of B cells and antibody to cardiac allograft vasculopathy. Transplantation. 2009;88(4):470-7. doi:10.1097/TP.0b013e3181b076cc.

45. Pratt JR, Basheer SA, Sacks SH. Local synthesis of complement component $\mathrm{C} 3$ regulates acute renal transplant rejection. Nat Med. 2002;8(6):582-7. doi:10.1038/nm0602-582.

46. Pober JS, Tellides G. Participation of blood vessel cells in human adaptive immune responses. Trends Immunol. 2012;33(1):49-57. doi:10.1016/j.it.2011.09.006.

47. Hook S, Caple JF, McMahon JT, Myles JL, Ratliff NB. Comparison of myocardial cell injury in acute cellular rejection versus acute vascular rejection in cyclosporine-treated heart transplants. J Heart Lung Transplant Off Publ Int Soc Heart Transplant. 1995;14(2):351-8

48. Mehra MR, Crespo-Leiro MG, Dipchand A, Ensminger SM, Hiemann NE, Kobashigawa JA, et al. International Society for Heart and Lung Transplantation working formulation of a standardized nomenclature for cardiac allograft vasculopathy2010. J Heart Lung Transplant Off Publ Int Soc Heart Transplant. 2010;29(7):717-27. doi:10.1016/j.healun.2010. 05.017.

49. Berry GJ, Angelini A, Burke MM, Bruneval P, Fishbein MC, Hammond E, et al. The ISHLT working formulation for pathologic diagnosis of antibody-mediated rejection in heart transplantation: evolution and current status (2005-2011). J Heart Lung Transplant Off Publ Int Soc Heart Transplant. 2011;30(6):601-11. doi:10. 1016/j.healun.2011.02.015.

50.• Berry GJ, Burke MM, Andersen C, Bruneval P, Fedrigo M, Fishbein MC, et al. The 2013 International Society for Heart and Lung Transplantation Working Formulation for the standardization of nomenclature in the pathologic diagnosis of antibodymediated rejection in heart transplantation. J Heart Lung Transplant Off Publ Int Soc Heart Transplant. 2013;32(12): 1147-62. doi:10.1016/j.healun.2013.08.011. The official new nomenclature for the diagnosis of cardiac AMR.

51. Colvin RB, Smith RN. Antibody-mediated organ-allograft rejection. Nat Rev Immunol. 2005;5(10):807-17. doi:10.1038/nri1702.

52. Hammond EH, Hansen JK, Spencer LS, Jensen A, Riddell D, Craven CM, et al. Vascular rejection in cardiac transplantation: Histologic, Immunopathologic, and Ultrastructural Features. Cardiovasc Pathol Off J Soc Cardiovasc Pathol. 1993;2(1):21-34.

53. Fedrigo M, Feltrin G, Poli F, Frigo AC, Benazzi E, Gambino A, et al. Intravascular macrophages in cardiac allograft biopsies for diagnosis of early and late antibody-mediated rejection. J Heart Lung Transplant Off Publ Int Soc Heart Transplant. 2013;32(4): 404-9. doi:10.1016/j.healun.2012.12.017.

54. Wehner JR, Morrell CN, Rodriguez ER, Fairchild RL, Baldwin 3rd WM. Immunological challenges of cardiac transplantation: the need for better animal models to answer current clinical questions.
J Clin Immunol. 2009;29(6):722-9. doi:10.1007/s10875-0099334-4.

55. Hammond EH, Wittwer CT, Greenwood J, Knape WA, Yowell RL, Menlove RL, et al. Relationship of OKT3 sensitization and vascular rejection in cardiac transplant patients receiving OKT3 rejection prophylaxis. Transplantation. 1990;50(5):776-82.

56. Tan CD, Sokos GG, Pidwell DJ, Smedira NG, GonzalezStawinski GV, Taylor DO, et al. Correlation of donor-specific antibodies, complement and its regulators with graft dysfunction in cardiac antibody-mediated rejection. Am J Transplant Off J Am Soc Transplant Am Soc Transplant Surg. 2009;9(9):2075-84. doi: 10.1111/j.1600-6143.2009.02748.x.

57. Tible M, Loupy A, Vernerey D, Suberbielle C, Beuscart T, Cazes A, et al. Pathologic classification of antibody-mediated rejection correlates with donor-specific antibodies and endothelial cell activation. J Heart Lung Transplant Off Publ Int Soc Heart Transplant. 2013;32(8):769-76. doi:10.1016/j.healun.2013.05.012.

58. Almuti K, Haythe J, Dwyer E, Itescu S, Burke E, Green P, et al. The changing pattern of humoral rejection in cardiac transplant recipients. Transplantation. 2007;84(4):498-503. doi:10.1097/01. tp.0000278094.41131.9f.

59. Fishbein MC, Kobashigawa J. Biopsy-negative cardiac transplant rejection: etiology, diagnosis, and therapy. Curr Opin Cardiol. 2004;19(2):166-9.

60. Kfoury AG, Hammond ME, Snow GL, Stehlik J, Reid BB, Long JW, et al. Early screening for antibody-mediated rejection in heart transplant recipients. J Heart Lung Transplant Off Publ Int Soc Heart Transplant. 2007;26(12):1264-9. doi:10.1016/j.healun. 2007.09.011.

61. Michaels PJ, Fishbein MC, Colvin RB. Humoral rejection of human organ transplants. Springer Semin Immunopathol. 2003;25(2):119-40. doi:10.1007/s00281-003-0139-x.

62. Budge D, Khan F, Hammond E, Nelson Z, Stehlik J, Alharethi R, et al. Safety and Outcomes with Newer Treatment Strategies for Cardiac Antibody-mediated Rejection: Still in the Woods. J Heart Lung transplant Off Publ Int Soc Heart Transplant. 2010;29(2S): S42.

63. Crespo-Leiro MG, Veiga-Barreiro A, Domenech N, Paniagua MJ, Pinon P, Gonzalez-Cuesta M, et al. Humoral heart rejection (severe allograft dysfunction with no signs of cellular rejection or ischemia): incidence, management, and the value of $\mathrm{C} 4 \mathrm{~d}$ for diagnosis. Am J Transplant Off J Am Soc Transplant Am Soc Transplant Surg. 2005;5(10):2560-4. doi:10.1111/j.1600-6143. 2005.01039.x.

64. Garrett Jr HE, Duvall-Seaman D, Helsley B, Groshart K. Treatment of vascular rejection with rituximab in cardiac transplantation. J Heart Lung Transplant Off Publ Int Soc Heart Transplant. 2005;24(9):1337-42. doi:10.1016/j.healun.2004.09. 003.

65. Kfoury AG, Hammond ME, Snow GL, Drakos SG, Stehlik J, Fisher PW, et al. Cardiovascular mortality among heart transplant recipients with asymptomatic antibody-mediated or stable mixed cellular and antibody-mediated rejection. J Heart Lung Transplant Off Publ Int Soc Heart Transplant. 2009;28(8):781-4. doi:10. 1016/j.healun.2009.04.035.

66. Kfoury AG, Snow GL, Budge D, Alharethi RA, Stehlik J, Everitt $\mathrm{MD}$, et al. A longitudinal study of the course of asymptomatic antibody-mediated rejection in heart transplantation. J Heart Lung Transplant Off Publ Int Soc Heart Transplant. 2012;31(1):46-51. doi:10.1016/j.healun.2011.10.009.

67. Kfoury AG, Stehlik J, Renlund DG, Snow G, Seaman JT, Gilbert EM, et al. Impact of repetitive episodes of antibody-mediated or cellular rejection on cardiovascular mortality in cardiac transplant recipients: defining rejection patterns. J Heart Lung Transplant Off Publ Int Soc Heart Transplant. 2006;25(11):1277-82. doi:10. 1016/j.healun.2006.08.009. 
68. Miller LW, Wesp A, Jennison SH, Graham MA, Martin TW, McBride LR, et al. Vascular rejection in heart transplant recipients. J Heart Lung Transplant Off Publ Int Soc Heart Transplant. 1993;12(2):S147-52.

69. Olsen SL, Wagoner LE, Hammond EH, Taylor DO, Yowell RL, Ensley RD, et al. Vascular rejection in heart transplantation: clinical correlation, treatment options, and future considerations. J Heart Lung Transplant Off Publ Int Soc Heart Transplant. 1993;12(2):S135-42.

70. Tambur AR, Pamboukian SV, Costanzo MR, Herrera ND, Dunlap $\mathrm{S}$, Montpetit M, et al. The presence of HLA-directed antibodies after heart transplantation is associated with poor allograft outcome. Transplantation. 2005;80(8):1019-25.

71. Taylor DO, Yowell RL, Kfoury AG, Hammond EH, Renlund DG. Allograft coronary artery disease: clinical correlations with circulating anti-HLA antibodies and the immunohistopathologic pattern of vascular rejection. J Heart Lung Transplant Off Publ Int Soc Heart Transplant. 2000;19(6):518-21.

72. Wu GW, Kobashigawa JA, Fishbein MC, Patel JK, Kittleson MM, Reed EF, et al. Asymptomatic antibody-mediated rejection after heart transplantation predicts poor outcomes. J Heart Lung Transplant Off Publ Int Soc Heart Transplant. 2009;28(5):41722. doi:10.1016/j.healun.2009.01.015.

73. Costanzo MR, Dipchand A, Starling R, Anderson A, Chan M, Desai S, et al. The International Society of Heart and Lung Transplantation Guidelines for the care of heart transplant recipients. J Heart Lung Transplant Off Publ Int Soc Heart Transplant. 2010;29(8):914-56. doi:10.1016/j.healun.2010.05.034.

74. Grauhan O, Knosalla C, Ewert R, Hummel M, Loebe M, Weng YG, et al. Plasmapheresis and cyclophosphamide in the treatment of humoral rejection after heart transplantation. J Heart Lung Transplant Off Publ Int Soc Heart Trans. 2001;20(3):316-21.

75. Hershko AY, Naparstek Y. Removal of pathogenic autoantibodies by immunoadsorption. Ann N Y Acad Sci. 2005;1051:635-46. doi:10.1196/annals.1361.108.

76. Rummler S, Barz D. Plasma Exchange and Immunoadsorption of Patients with Thoracic Organ Transplantation. Transf Med Hemother Off Organ Dtsch Ges Transfusion Immunhamatol. 2012;39(4):234-40. doi:10.4459/000341676.

77. Allen NH, Dyer P, Geoghegan T, Harris K, Lee HA, Slapak M. Plasma exchange in acute renal allograft rejection. A controlled trial. Transplantation. 1983;35(5):425-8.

78. Blake P, Sutton D, Cardella CJ. Plasma exchange in acute renal transplant rejection. Prog Clin Biol Res. 1990;337:249-52.

79. Bonomini V, Vangelista A, Frasca GM, Di Felice A, D'Arcangelo LG. Effects of plasmapheresis in renal transplant rejection A controlled study. Trans Am Soc Artif Int Organs. 1985;31:698703 .

80. Djamali A, Kaufman DB, Ellis TM, Zhong W, Matas A, Samaniego M. Diagnosis and management of antibodymediated rejection: current status and novel approaches. Am J Transplant Off J Am Soc Transplant Am Soc Transplant Surg. 2014;14(2):255-71. doi:10.1111/ajt.12589.

81. Kirubakaran MG, Disney AP, Norman J, Pugsley DJ, Mathew TH. A controlled trial of plasmapheresis in the treatment of renal allograft rejection. Transplantation. 1981;32(2):164-5.

82. Jordan SC, Toyoda M, Vo AA. Intravenous immunoglobulin a natural regulator of immunity and inflammation. Transplantation. 2009;88(1):1-6. doi:10.1097/TP.0b013e3181a9e89a.

83. Jordan SC, Toyoda M, Kahwaji J, Vo AA. Clinical aspects of intravenous immunoglobulin use in solid organ transplant recipients. Am J Transplant Off J Am Soc Transplant Am Soc Transplant Surg. 2011;11(2):196-202. doi:10.1111/j.1600-6143. 2010.03400.x.
84. Nimmerjahn F, Ravetch JV. Anti-inflammatory actions of intravenous immunoglobulin. Annu Rev Immunol. 2008;26:513-33. doi: 10.1146/annurev.immunol.26.021607.090232.

85. Rodriguez ER, Skojec DV, Tan CD, Zachary AA, Kasper EK, Conte JV, et al. Antibody-mediated rejection in human cardiac allografts: evaluation of immunoglobulins and complement activation products $\mathrm{C} 4 \mathrm{~d}$ and $\mathrm{C} 3 \mathrm{~d}$ as markers. Am J Transplant Off J Am Soc Transplant Am Soc Transplant Surg. 2005;5(11):2778 85. doi:10.1111/j.1600-6143.2005.01074.x.

86. Shehata N, Palda VA, Meyer RM, Blydt-Hansen TD, Campbell P, Cardella $\mathrm{C}$, et al. The use of immunoglobulin therapy for patients undergoing solid organ transplantation: an evidence-based practice guideline. Transfus Med Rev. 2010;24 Suppl 1:S7-27. doi:10. 1016/j.tmrv.2009.09.010.

87. Leech SH, Lopez-Cepero M, LeFor WM, DiChiara L, Weston M, Furukawa S, et al. Management of the sensitized cardiac recipient: the use of plasmapheresis and intravenous immunoglobulin. Clin Transpl. 2006;20(4):476-84. doi:10.1111/j.1399-0012.2006. 00509.x.

88. Locke JE, Magro CM, Singer AL, Segev DL, Haas M, Hillel AT, et al. The use of antibody to complement protein C5 for salvage treatment of severe antibody-mediated rejection. Am J Transplant Off J Am Soc Transplant Am Soc Transplant Surg. 2009;9(1): 231-5. doi:10.1111/j.1600-6143.2008.02451.x.

89. Stewart ZA, Collins TE, Schlueter AJ, Raife TI, Holanda DG, Nair R, et al. Case report: Eculizumab rescue of severe accelerated antibody-mediated rejection after ABO-incompatible kidney transplant. Transplant Proc. 2012;44(10):3033-6. doi:10.1016/j. transproceed.2012.03.053.

90. Gonzalez-Roncero F, Suner M, Bernal G, Cabello V, Toro M, Pereira $\mathrm{P}$, et al. Eculizumab treatment of acute antibody-mediated rejection in renal transplantation: case reports. Transplant Proc. 2012;44(9):2690-4. doi:10.1016/j.transproceed.2012.09.038.

91. Noone D, Al-Matrafi J, Tinckam K, Zipfel PF, Herzenberg AM, Thorner PS, et al. Antibody mediated rejection associated with complement factor h-related protein 3/1 deficiency successfully treated with eculizumab. Am J Transplant Off J Am Soc Transplant Am Soc Transplant Surg. 2012;12(9):2546-53. doi: 10.1111/j.1600-6143.2012.04124.x.

92. Dawson KL, Parulekar A, Seethamraju H. Treatment of hyperacute antibody-mediated lung allograft rejection with eculizumab. J Heart Lung Transplant Off Publ Int Soc Heart Transplant. 2012;31(12):1325-6. doi:10.1016/j.healun.2012.09.016.

93. Ghirardo G, Benetti E, Poli F, Vidal E, Della Vella M, Cozzi E, et al. Plasmapheresis-resistant acute humoral rejection successfully treated with anti-C5 antibody. Pediatr Transplant. 2014;18(1): E1-5. doi:10.1111/petr.12187.

94. Kocak B, Arpali E, Demiralp E, Yelken B, Karatas C, Gorcin S, et al. Eculizumab for salvage treatment of refractory antibodymediated rejection in kidney transplant patients: case reports. Transplant Proc. 2013;45(3):1022-5. doi:10.1016/j.transproceed. 2013.02.062.

95. Garrett Jr HE, Groshart K, Duvall-Seaman D, Combs D, Suggs R. Treatment of humoral rejection with rituximab. Ann Thorac Surg. 2002;74(4):1240-2.

96. Aranda Jr JM, Scornik JC, Normann SJ, Lottenberg R, Schofield RS, Pauly DF, et al. Anti-CD20 monoclonal antibody (rituximab) therapy for acute cardiac humoral rejection: a case report. Transplantation. 2002;73(6):907-10.

97. Baran DA, Lubitz S, Alvi S, Fallon JT, Kaplan S, Galin I, et al. Refractory humoral cardiac allograft rejection successfully treated with a single dose of rituximab. Transplant Proc. 2004;36(10): 3164-6. doi:10.1016/j.transproceed.2004.10.087.

98. Kaczmarek I, Deutsch MA, Sadoni S, Brenner P, Schmauss D, Daebritz SH, et al. Successful management of antibody-mediated cardiac allograft rejection with combined immunoadsorption and 
anti-CD20 monoclonal antibody treatment: case report and literature review. J Heart Lung Trans Off Publ Int Soc Heart Trans. 2007;26(5):511-5. doi:10.1016/j.healun.2007.01.027.

99. Aggarwal A, Pyle J, Hamilton J, Bhat G. Low-dose rituximab therapy for antibody-mediated rejection in a highly sensitized heart-transplant recipient. Tex Heart Inst J Tex Heart Inst St Luke's Episcopal Hosp Tex Child Hosp. 2012;39(6):901-5.

100. Hodges AM, Lyster H, McDermott A, Rice AJ, Smith JD, Rose ML, et al. Late antibody-mediated rejection after heart transplantation following the development of de novo donor-specific human leukocyte antigen antibody. Transplantation. 2012;93(6): 650-6. doi:10.1097/TP.0b013e318244f7b8.

101. Ravichandran AK, Schilling JD, Novak E, Pfeifer J, Ewald GA, Joseph SM. Rituximab is associated with improved survival in cardiac allograft patients with antibody-mediated rejection: a single center review. Clin Transpl. 2013;27(6):961-7. doi:10.1111/ ctr.12277.

102. Cantarovich M, Latter DA, Loertscher R. Treatment of steroid-resistant and recurrent acute cardiac transplant rejection with a short course of antibody therapy. Clin Transpl. 1997;11(4):316-21.

103. Jirasiritham S, Khunprakant R, Techawathanawanna N, Jirasiritham S, Mavichak V. Treatment of simultaneous acute antibody-mediated rejection and acute cellular rejection with alemtuzumab in kidney transplantation: a case report. Transplant Proc. 2010;42(3):987-9. doi:10.1016/j.transproceed.2010.03. 018.

104. van den Hoogen MW, Hesselink DA, van Son WJ, Weimar W, Hilbrands LB. Treatment of steroid-resistant acute renal allograft rejection with alemtuzumab. Am J Tran Off J Am Soc Trans Am Soc Transplant Surg. 2013;13(1):192-6. doi:10.1111/j.16006143.2012.04328.x.

105. Fassbinder W, Scheuermann EH, Stutte HJ, Bechstein PB, Fursch A, Ernst W, et al. Improved graft prognosis by treatment of steroid resistant rejections with ATG and plasmapheresis. Proc Eur Dial Transplant Assoc Eur Dial Transplant Assoc. 1983;20:362-7.

106. Shah A, Nadasdy T, Arend L, Brennan J, Leong N, Coppage M, et al. Treatment of C4d-positive acute humoral rejection with plasmapheresis and rabbit polyclonal antithymocyte globulin. Transplantation. 2004;77(9):1399-405.

107. Vincenti F, Cohen SD, Appel G. Novel B cell therapeutic targets in transplantation and immune-mediated glomerular diseases. Clin $\mathrm{J}$ Am Soc Nephrol CJASN. 2010;5(1):142-51. doi:10.2215/CJN. 04580709.

108. Ostergaard M, Baslund B, Rigby W, Rojkovich B, Jorgensen C, Dawes PT, et al. Ofatumumab, a human anti-CD20 monoclonal antibody, for treatment of rheumatoid arthritis with an inadequate response to one or more disease-modifying antirheumatic drugs: results of a randomized, double-blind, placebo-controlled, phase I/II study. Arthritis Rheum. 2010;62(8):2227-38. doi:10.1002/ art.27524.

109. Cang S, Mukhi N, Wang K, Liu D. Novel CD20 monoclonal antibodies for lymphoma therapy. J Hematol Oncol. 2012;5:64. doi:10.1186/1756-8722-5-64.

110. Tak PP, Mease PJ, Genovese MC, Kremer J, Haraoui B, Tanaka Y, et al. Safety and efficacy of ocrelizumab in patients with rheumatoid arthritis and an inadequate response to at least one tumor necrosis factor inhibitor: results of a forty-eight-week randomized, double-blind, placebo-controlled, parallel-group phase III trial. Arthritis Rheum. 2012;64(2):360-70.

111. Lulu S, Waubant E. Humoral-targeted immunotherapies in multiple sclerosis. Neurother J Am Soc Exp NeuroTher. 2013;10(1): 34-43. doi:10.1007/s13311-012-0164-3.

112. Dorner T, Kaufmann J, Wegener WA, Teoh N, Goldenberg DM, Burmester GR. Initial clinical trial of epratuzumab (humanized
anti-CD22 antibody) for immunotherapy of systemic lupus erythematosus. Arthritis Res Ther. 2006;8(3):R74. doi:10.1186/ $\operatorname{ar} 1942$.

113. Tedder TF. CD19: a promising B cell target for rheumatoid arthritis. Nat Rev Rheumatol. 2009;5(10):572-7. doi:10.1038/nrrheum. 2009.184.

114. Lateef A, Petri M. Biologics in the treatment of systemic lupus erythematosus. Curr Opin Rheumatol. 2010;22(5):504-9. doi:10. 1097/BOR.0b013e32833b475e.

115. Looney RJ. B cell-targeted therapies for systemic lupus erythematosus: an update on clinical trial data. Drugs. 2010;70(5):529-40. doi:10.2165/11535420-000000000-00000.

116. Kalunian KC, Davis Jr JC, Merrill JT, Totoritis MC, Wofsy D, Group I-LS. Treatment of systemic lupus erythematosus by inhibition of $\mathrm{T}$ cell costimulation with anti-CD154: a randomized, double-blind, placebo-controlled trial. Arthritis Rheum. 2002;46(12):3251-8. doi:10.1002/art.10681.

117. Boumpas DT, Furie R, Manzi S, Illei GG, Wallace DJ, Balow JE, et al. A short course of BG9588 (anti-CD40 ligand antibody) improves serologic activity and decreases hematuria in patients with proliferative lupus glomerulonephritis. Arthritis Rheum. 2003;48(3):719-27. doi:10.1002/art.10856.

118. Kirk AD, Knechtle SJ, Sollinger HE. Preliminary results of the use of humanized anti-CD154 in human renal allotrasnplantation. Am J Trans Off J Am Soc Trans Am Soc Transplant Surg. 2001;1(191):suppl 1.

119. Clatworthy MR. Targeting B, cells and antibody in transplantation. Am J Trans Off J Am Soc Trans Am Soc Trans Surg. 2011;11(7): 1359-67. doi:10.1111/j.1600-6143.2011.03554.x.

120. Everly JJ, Walsh RC, Alloway RR, Woodle ES. Proteasome inhibition for antibody-mediated rejection. Curr Opin Organ Trans. 2009;14(6):662-6. doi:10.1097/MOT.0b013e328330f304.

121. Eckman PM, Thorsgard M, Maurer D, Kim Y, Alloway RR, Woodle ES. Bortezomib for refractory antibody-mediated cardiac allograft rejection. Clin Trans. 2009:475-8.

122. Trivedi HL, Terasaki PI, Feroz A, Everly MJ, Vanikar AV, Shankar $\mathrm{V}$, et al. Abrogation of anti-HLA antibodies via proteasome inhibition. Transplantation. 2009;87(10):1555-61. doi:10.1097/TP. 0b013e3181a4b91b.

123. Morrow WR, Frazier EA, Mahle WT, Harville TO, Pye SE, Knecht KR, et al. Rapid reduction in donor-specific anti-human leukocyte antigen antibodies and reversal of antibody-mediated rejection with bortezomib in pediatric heart transplant patients. Transplantation. 2012;93(3):319-24. doi:10.1097/TP. 0b013e31823f7eea.

124. Everly MJ, Terasaki PI, Hopfield J, Trivedi HL, Kaneku H. Protective immunity remains intact after antibody removal by means of proteasome inhibition. Transplantation. 2010;90(12): 1493-8. doi:10.1097/TP.0b013e3181ff87b1.

125. Zand MS. B-cell activity of polyclonal antithymocyte globulins. Transplantation. 2006;82(11):1387-95. doi:10.1097/01.tp. 0000244063.05338 .27$.

126. Zand MS, Vo T, Huggins J, Felgar R, Liesveld J, Pellegrin T, et al. Polyclonal rabbit antithymocyte globulin triggers B-cell and plasma cell apoptosis by multiple pathways. Transplantation. 2005;79(11):1507-15.

127. Kim HS, Raskova J, Degiannis D, Raska Jr K. Effects of cyclosporine and rapamycin on immunoglobulin production by preactivated human B cells. Clin Exp Immunol. 1994;96(3): 508-12.

128. Heidt S, Roelen DL, Eijsink C, van Kooten C, Claas FH, Mulder A. Effects of immunosuppressive drugs on purified human B cells: evidence supporting the use of MMF and rapamycin. Transplantation. 2008;86(9):1292-300. doi:10.1097/TP. 0b013e3181874a36. 